\title{
Online Securities Trading in China
}

\author{
Michelle W. L. Fong \\ Victoria University, Melbourne, Australia
}

Michelle.Fong@vu.edu.au

\begin{abstract}
This paper looks at the adoption of information technology in the Chinese stock exchanges and for online securities trading in China. Because these stock exchanges do not have any major preexisting technology to consider when they automate their operations, they are able to adopt advanced technology. However, the potential and advantages offer by this technology cannot be fully harvested without fundamental structures and proper corporate governance mechanisms in place.
\end{abstract}

Keywords: stock exchange, online securities trading, securities brokerage firms, Internet, seamless integration.

\section{Introduction}

Information technology is a linchpin to the operation of securities markets around the world. Fully computerized trading facilities are growing in importance in these markets, and automation of trading processes through information technology has radically changed the speed of securities trading. Several stock exchange floors, on which brokers manually matched orders using an open-cry system, have been replaced by or are being converted to electronic trading systems. In these markets, information technology is also being adopted to globalize trading and settlement activities, enabling investors to trade in different markets regardless of time and location. For market economies, this electronic linkage capability of information technology facilitates the daily flow of capital through markets, offering the potential of creating a thriving securities market (Levitt, 1989; Malone, Yates, \& Benjamin, 1987). Amihud and Mendelson (1989) demonstrated in their study that market liquidity could be enhanced through the proper use of information technology. (Liquidity in securities market refers to the ability to quickly buy or sell a share without causing a significant movement in the price. Liquidity is one of the most important characteristics of a good market.)

Automation of capital markets has also been found to have instilled or enhanced transparency in market activities to an extent, with respect to price and trade information (Brailsford, Frino, Hodgson, \& West, 1999; Grunbichler, Longstaff, \& Schwartz, 1994; Hamilton, 1978; Jassawalla, 1989; Nabi, 2004; Picot, Bortenlaenger, Roehrl, 1995). Brailsford et al. (1999) found that the automation of the stock market resulted in an increase of around $77 \%$ in contemporaneous public information transfer. With the entire bid-and-ask schedule and course of sales available on an al-

Material published as part of this journal, either on-line or in print, is copyrighted by Informing Science. Permission to make digital or paper copy of part or all of these works for personal or classroom use is granted without fee provided that the copies are not made or distributed for profit or commercial advantage AND that copies 1) bear this notice in full and 2) give the full citation on the first page. It is permissible to abstract these works so long as credit is given. To copy in all other cases or to republish or to post on a server or to redistribute to lists requires specific permission from the publisher at Publisher@InformingScience.org most real-time basis, and directly to all market participants, investors do not have to rely on brokers for this information. On the part of brokers, they do not have to undertake a physical search for the appropriate party to fulfill a sell or buy order raised by their clients in these markets. A fully 
automated trading system matches sell and buy orders, regardless of size of stock portfolios, and is considerably faster than physical floor trading, which can result in lower transaction costs for participants in the market.

This paper looks at the adoption of information technology in the Chinese stock exchanges and for online securities trading in China. Because these stock exchanges do not have any major preexisting technology to consider when they automate their operations, they are able to adopt advanced technology. However, the potential and advantages offer by this technology cannot be fully harvested without fundamental structures and proper corporate governance mechanisms in place. IT plays a crucial role in market operations but a successful market infrastructure is a key resource.

\section{Chinese Stock Markets}

The first stock market was established in Shanghai in 1891 but was forced to shut down during the Japanese invasion in 1941. The Cultural Revolution and political disruptions kept this market shut until the end of the Mao era, at which point the new communist leader, Deng Xiaoping, opened its economy to trade. The stock market in China was revived with the re-establishment of the Shanghai Stock Exchange in December 1990. In July 1991, a second stock exchange, Shenzhen Stock Exchange, was opened for trading. Since the official re-establishment or opening of these exchanges, there has been an increase in stock market activities. Figure 1 shows the increases, on average, in market capitalization value, negotiable market capitalization value, and stock turnover in both Shanghai and Shenzhen Stock Exchanges between 1992 and 2003. A majority of the listed companies are state-owned companies, which issued three types of shares: state-owned shares, legal person shares (shares cross-held by companies), and tradeable shares (shares owned by individuals). Of these, only the tradeable shares can be traded in the stock market. Negotiable shares account for one-third of all shares, and they experienced an increase in activity over the years. In addition, Figure 2 shows a clear trend of increase in the number of investors, number of listed companies issuing A- and B-shares, and number of shares issued during the same period. The increase in stock market activities and number of participants has been generating pressure on both the operating capacity of the exchanges and on the ability of the China Securities Regulatory Commission (CSRS), which is China's securities market watchdog, to regulate the market effectively.

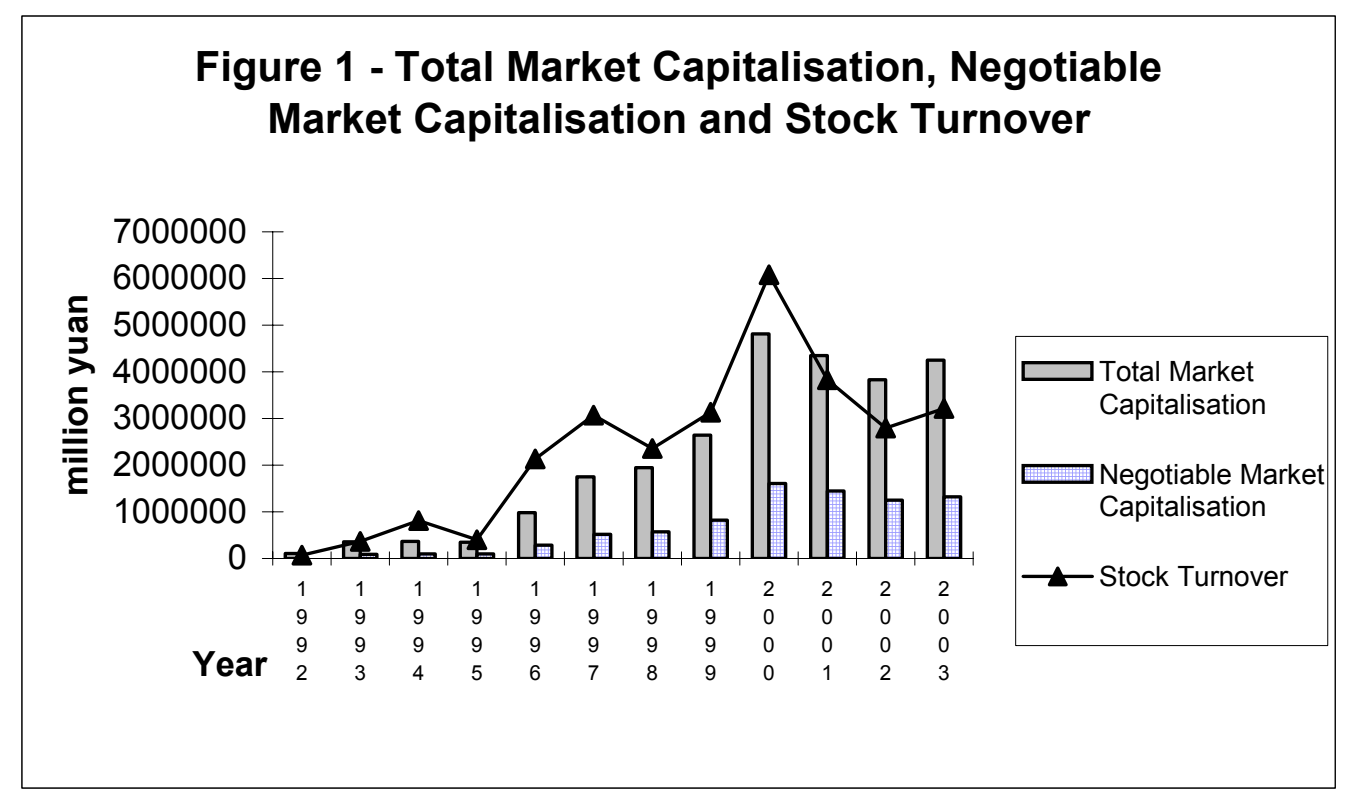




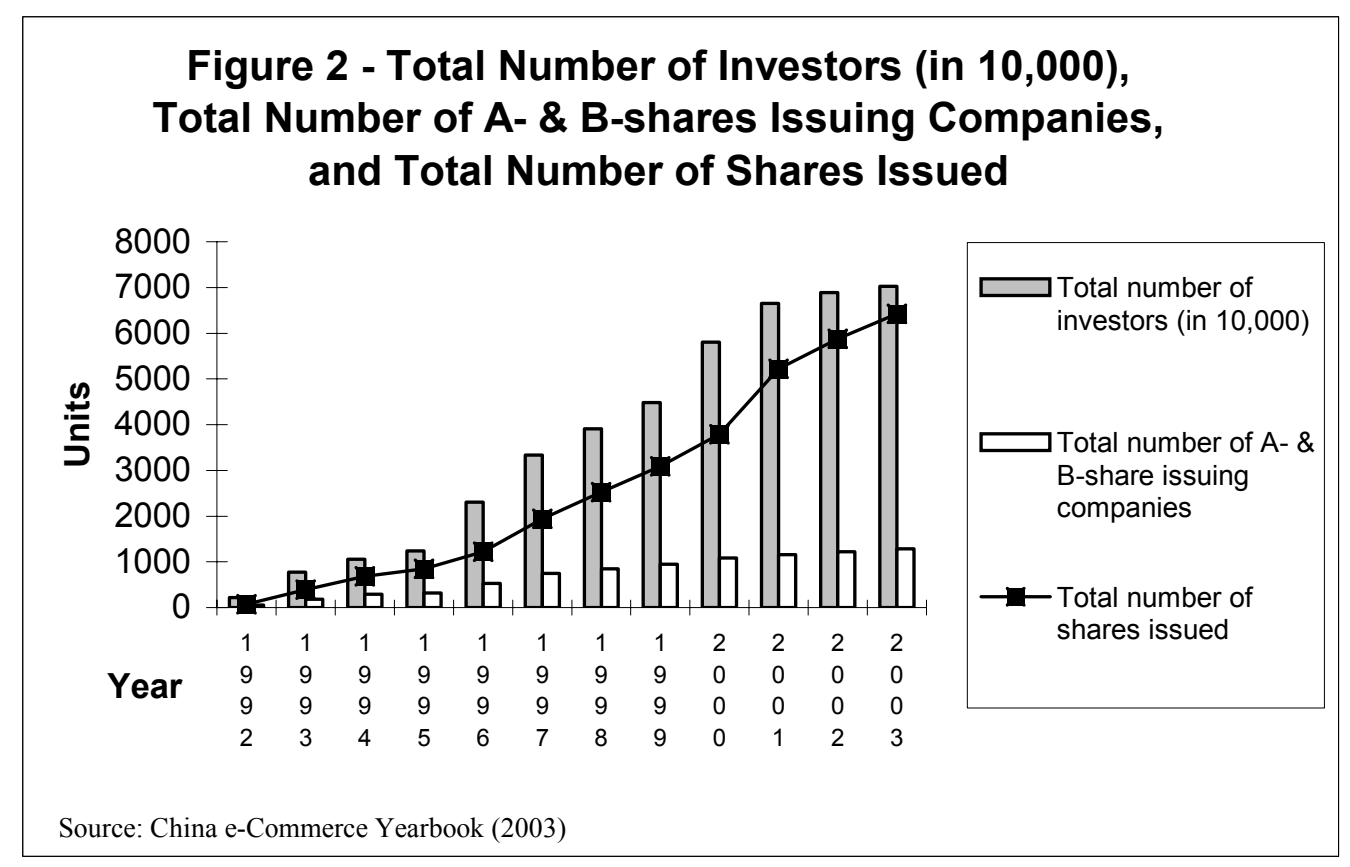

\section{Information Technology Adoption}

The long-term closure of the Chinese stock markets and the new locations for these exchanges obviously means that systems and procedures can be developed from scratch. China's stock exchanges were in a position to adopt advanced information technology at their early stage of reestablishment because they are not inhibited by any previous intermediate technology structure that may have required high displacement or integration costs.

Foreign observers were impressed by the advanced technology adopted by the Chinese stock exchanges. Trades were entered into computers rather than manually recorded on paper by clerks (Sender, 1994). In 1993, stock exchange offices in Guangdong, Guangzhou, Zhanjiang, Fujiang, Xiamen and Beijing were interconnected by the National Electronic Trading System (NETS) for the first time ("NETS progresses", 1993). This system is supported by satellite and is capable of handling trading and settlement transactions, as well as providing updated trading information to all market participants ("Shanghai stock", 2001). Because satellite technology is capable of supporting wide geographical coverage in communications, the network has evolved to connect stock exchanges and offices in several cities over the years. This technology paves the way for a national securities system offering investors from non-local markets an opportunity to participate in securities trading, and thereby bringing higher market liquidity than before ("Satellite communication", 1994). This information system has alleviated the bottleneck situation in the dissemination of market information for the Shanghai Stock Exchange ("Satellite information", 1993). Enhancements to this electronic system, such as improving processing capacity and settlement cycle, were undertaken to keep pace with market growth (GSCS Benchmarks, 2002; "Shanghai", 1993). The computer trading networks established by the Chinese stock exchange were of 1990s international computer and communication technology standard ("Stock exchanges", 2004). This electronic system has won accolades in the early 1990s for its capability to increase transaction productivity, fairness and transparency for the fledgling Chinese markets ("Zhejiang", 1993). For example, the computerized trading system, supported by satellite and digital data communication network, was able to handle as many as 10,000 transactions per second for the Shanghai Stock Exchange in 2002 ("Factbook", 2004). 
The Chinese authorities have also used technology as a tool to combat illegal trading activities (Wei, 1992). During the early re-establishment stage of the stock markets, it was found that trading activities were conducted outside exchanges or informal markets, but the authorities have since made strenuous efforts to encourage trading through the computerized system (Schroeder 1991; Soloman, 1996). In December 1990, China implemented a computerized quotation system that linked securities firms in six cities, in an attempt to eliminate speculation activities by making trading activities more transparent. Transparency is one of the best defenses against instability. In a similar bid for greater transparency in 2000, the CSRS required listed firms to post their annual and quarterly reports and disclosures on its webpage as well as the webpages of the two domestic exchanges ("China securities", 2004). This transparency is needed to boost investor confidence and improve the financial reporting systems of listed firms. Since 2000, the CSRS has been encouraging online trading for licensed brokerage firms in the securities markets. By 2001, CSRC had approved 23 of these firms to trade online (Asia.internet.com staff, 2001). Furthermore, the implementation in 2002 of new rules by the CSRS, to lower the price cap on brokerage fees, introduced price competition among securities brokerage firms. These rules have prompted brokerage services to adopt online trading as a mean of lowering transaction /operation costs in the face of keen market competition (Zhong, 2002).

\section{Online Securities Trading}

Licensed securities brokerage firms are the only participants permitted to apply to the CSRS for approval to conduct online trading of securities. Most brokerage firms outsource their online trading applications to IT companies or seek technical support from Application Service Providers (Asian technology newsletter, 2001). Non-securities companies such as Internet portals are banned from engaging in online securities brokerage or trading. The CSRC also requires Internet securities brokers to separate their online trading system from their other systems. Online trading services offered by the licensed brokerage firms enable investors to place orders with their brokers over the Internet. Besides being able to place offers and submit bids through the broker's electronic system, online users can also obtain stock prices and transaction information, receive real-time transaction responses, and access the bulletin boards of listed companies through securities brokers. Investors who want to undertake online trading will have to open an online trading account with licensed brokerage firms. Generally, the trading system verifies the order, encapsulates the data and forwards it to the stock exchange central trading system. Based on available data in 2001 and 2002, online trading volume has experienced an increase (as shown in Figure 3) since CSRS promulgated this method of trading to licensed securities brokerage firms. Figure 4 shows a breakdown of this increase in online trading volume into quarterly periods between 2001 and 2002. Despite the increase in online trading volume, the number of online trading accounts opened by investors shows a low adoption rate in this trading method as depicted by Figure 4 . The last quarter of 2002 shows there was an average of 2.5 online trading accounts to every 100 investors. In addition, online trading volume constitutes about $12 \%$ of total trading volume. Figure 5 shows that total number of online trading accounts was only $15 \%$ of the number of investors in the market in January 2003. 
Figure 3 - Online Securities Trading: 2001 and 2002

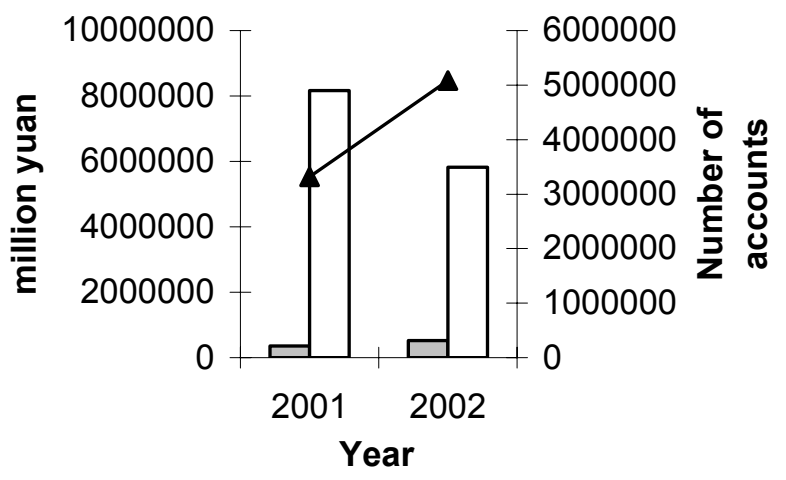

$\square$ Online trading volume (in million yuan)

Total trading volume (in million yuan)

$\rightarrow$ Number of online trading accounts

Figure 4 - Online Trading Indicators

\section{Percentage}

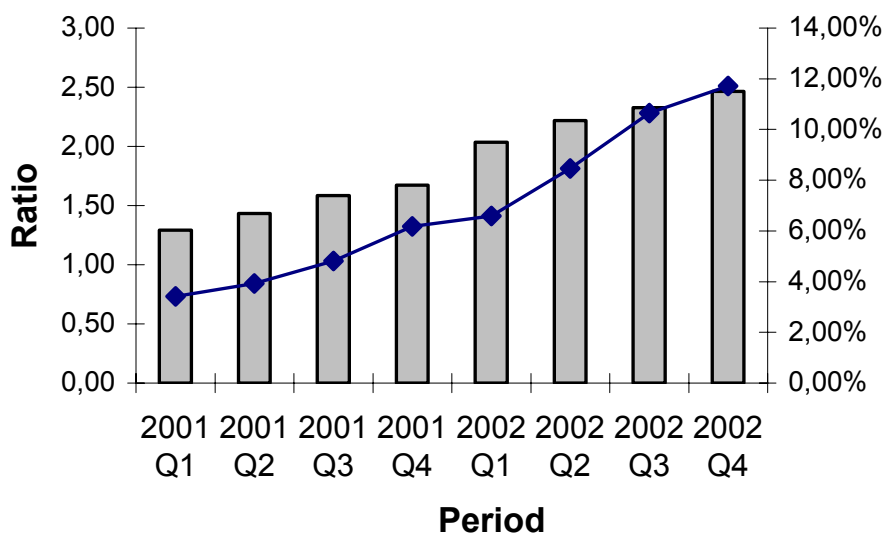

$\square$ Ratio of number of online trading accounts to every 100 investors

$\longrightarrow$ Online trading volume as a percentage of total trading volume

Source: China e-Commerce Yearbook (2003)

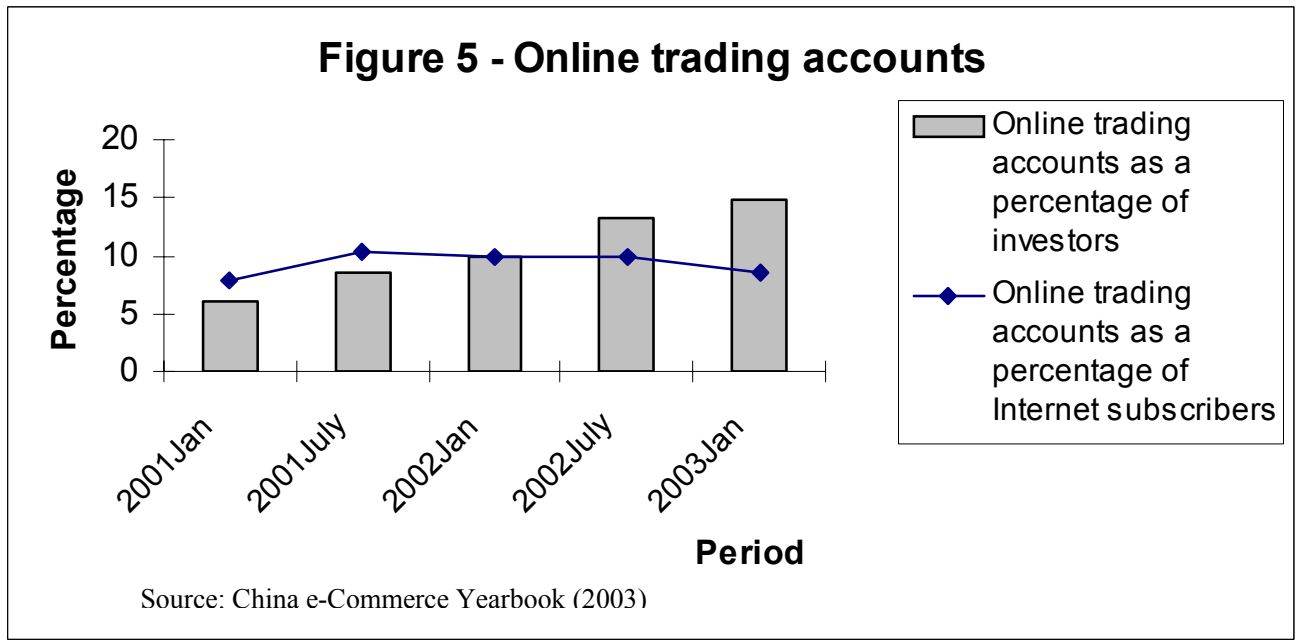


The number of Internet users in China has surged from 620,000 in October 1997 to 87 million in June, 2004 ("Statistical report", 2003, 2004) giving the country the second largest number of Internet connections in the world, after the USA (Internet World Stats, 2004). Despite the escalating increase in the rate of Chinese Internet connections over the years, the adoption rate for online securities trading by investors through the Internet is sluggish as shown in Figure 5. Online trading accounts constituted $8 \%$ to 10\% of Internet subscribers between January 2001 and January 2003. This low rate of adoption is also reflected in several Internet surveys undertaken by the China Internet Network Information Center between 1999 and 2004, when about 1\% to 6\% of respondents surveyed gave share trading as the reason for their Internet subscription (refer to Figure 6).

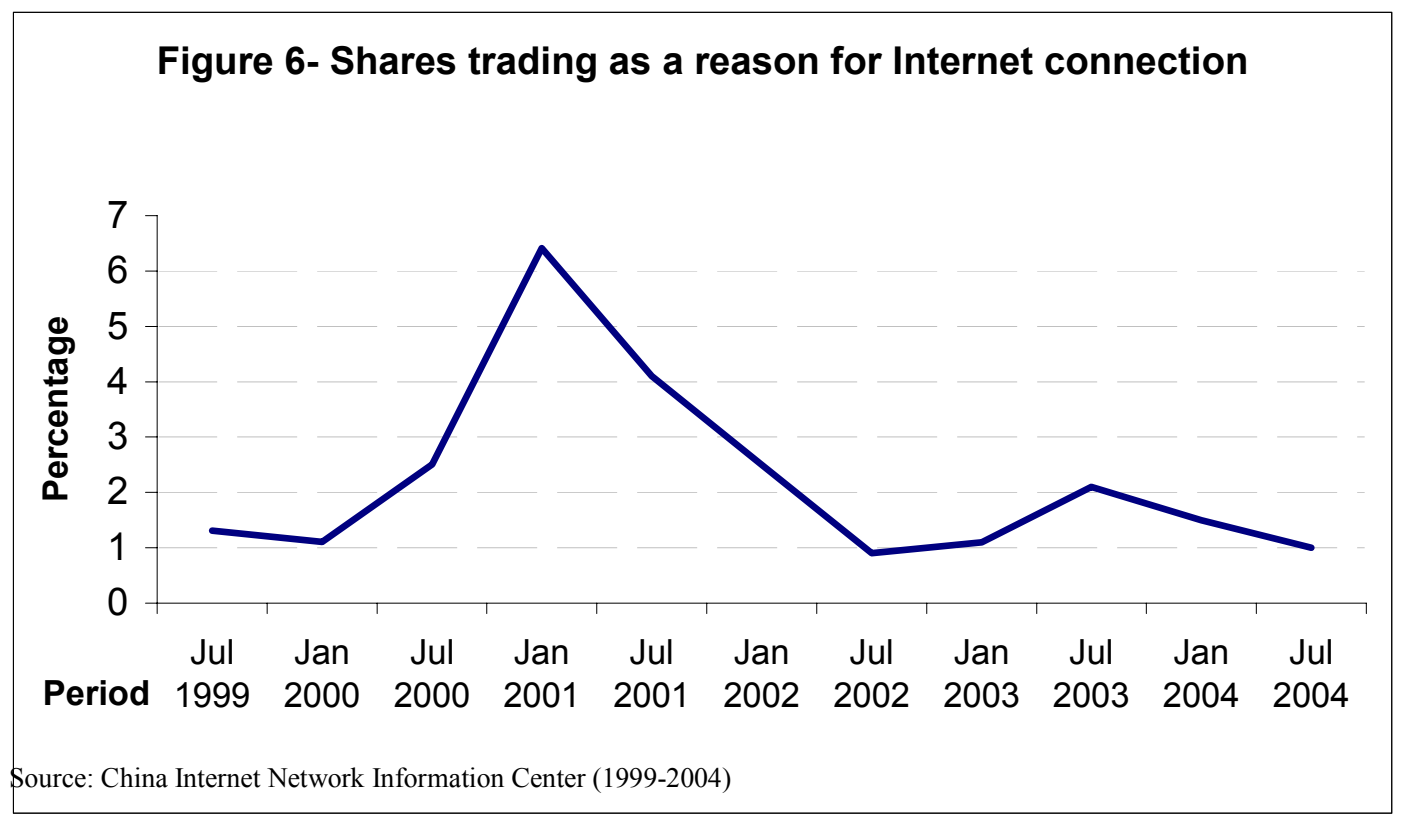

Figure 7 shows that Internet was the third most common transaction mode for securities trading for a sample of 73 securities brokerage firms in March 2001 and December 2002. Most trading were done over the telephone or over-the-counter at their business outlets. However, it seems that online trading via the Internet has increased in these periods (refer to Figure 7) although its growth cannot match the growth rate of Internet usage. 


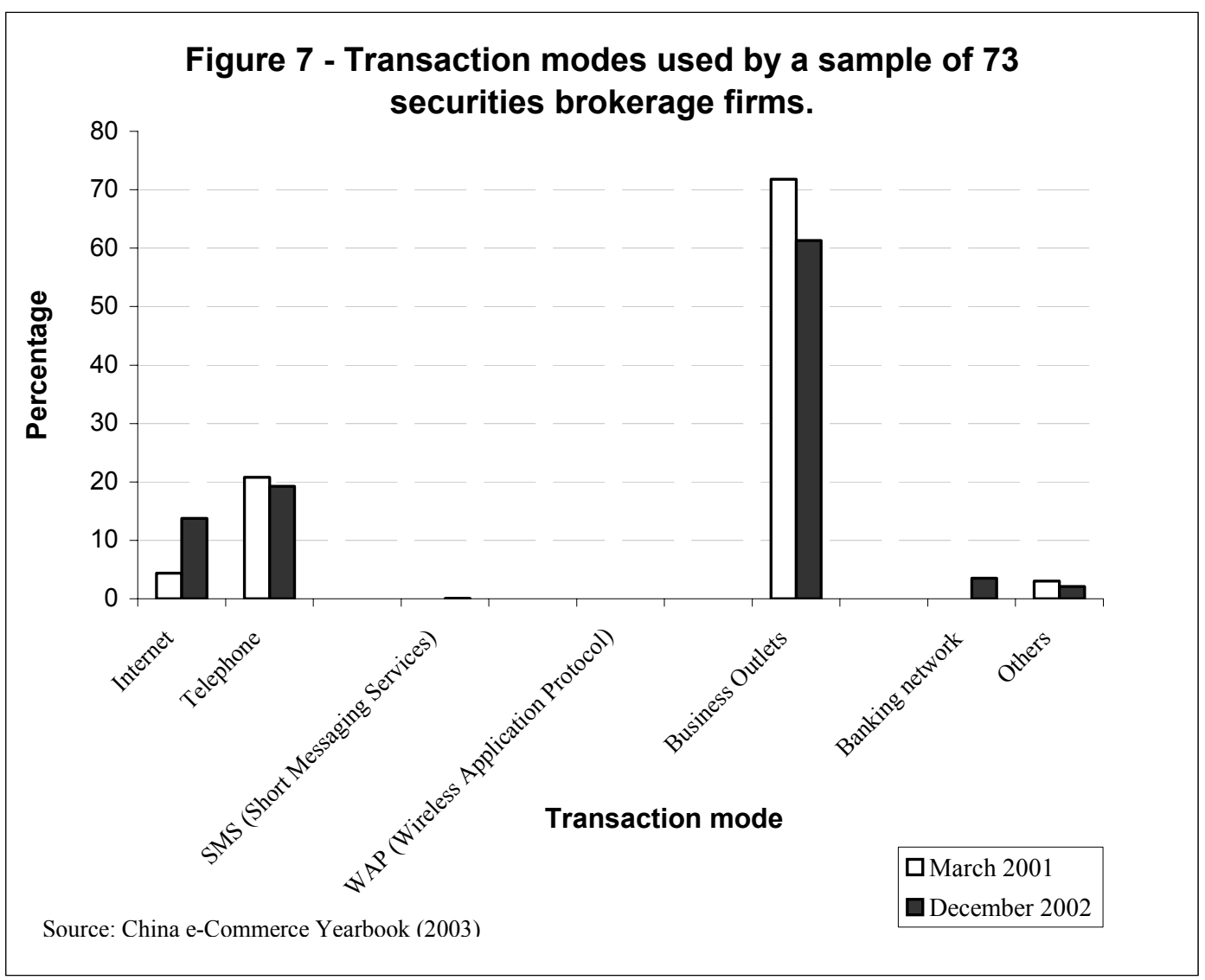

Issues

Although advanced technology has been adopted for the operation of the Chinese stock exchanges, the potential and advantages offered by this technology are yet to be properly and fully harvested, especially at the investor end. The factors that inhibit the Chinese ability to fully exploit information technology for e-trading are related not only to the low level of network interconnection with different investors in the market, but also to the underdeveloped infrastructure and support. Several aspects of this underdeveloped infrastructure and support are relevant:

1) The stability and security of Internet is a major issue in China. A survey conducted in 2004 found that viruses had infected $87.9 \%$ of computers in organizations, and is $2 \%$ higher than in 2003 ("Spam most”, 2004; "China's big", 2004). It was found that poor implementation of regulatory measures, low level of security awareness, ill-trained management staff in security, and the lack of an effective channel for secured transmission of information have contributed to lax application of security and ease of Internet security breaches. (It is generally believed that a $100 \%$ network security may not be possible at this current stage of technology development. However, with sound network security strategies and proper application of security policies and tools, network security risks can be managed and the chances of security breaches minimised.) The lack of stability and security in the Internet made investors cautious of online trading.

2) The IT architecture of securities brokerage firms in China tends to be limited in flexibility and scalability due to resource constraint. This prevents online trading system from functioning effectively when there is an unexpected increase in volume of transactions. On 24 June 2000, market reaction to certain information release created a surge in market activities, and transaction volume trebled. Systems in many securities brokerage firms were unable to cope with this surge in activi- 
ties and as a result, there was a network outage during which their investors were unable to conduct or close transactions. Although these firms have learned from this experience and upgraded the processing capacity in their electronic systems, weaknesses still exist, such as operating with the same business structure, unitary business type and low innovation capacity.

3) While information technology can help in preventing certain aspects of irregularities in market activities, its potential in realizing or supporting market efficiency can only be possible within an adequate legal framework and sound corporate governance structure. Technological changes pose challenges for the regulatory framework for securities markets. Although the regulatory and legal framework has been evolving to keep pace with the development of the stock market in China, there is still a problem with market reliability and transparency. Substantial effort is needed to establish an effective regulatory and legal framework, one that injects stability into the operating environment and boosts confidence among investors. Even though information technology is being used as a channel for improving transparency (by making financial reports and disclosures available to investors and the public through the Internet) the detrimental behavior of participants - providing false reports of business results, stock price manipulation and insider trading - remains to be deterred and eliminated by regulations. China's stock market definitely has a long path towards achieving seamless e-trading.

\section{Conclusion}

Since China's accession to the World Trade Organization (WTO) in November 2001, it is inevitable that its securities market will be opened to foreign participation, but the current development level of the Chinese securities market is substantially behind developed markets. Although foreign participation is likely to drive growth, China's stock market or securities sector will face significant challenges from foreign competition. China has to move rapidly to establish an operating environment where the potential of information technology can be effectively harnessed to achieve market efficiency.

The two Chinese stock exchanges did not have any major pre-existing technology to consider when they automated their operations, and were able to adopt advanced technology. However, the potential advantages offered by this technology cannot be fully harvested without fundamental structures and proper corporate governance mechanisms in place. There are non-technological factors that need to be further developed and considered in tandem with technology applications in order to achieve market efficiency and stability.

\section{References}

Amihud, Y. \& Mendelson, H. (1989). The effects of computer based trading on volatility and liquidity. In H. C. Lucas, Jr. \& R. A. Schwartz, (Eds.), The challenge of information technology for the securities markets: Liquidity, volatility, and global trading (pp. 59-85). The Saloman Brothers Centre for the Study of Financial Institutions.

Asia.internet.com staff. (2001, February 14). 23 China securities brokerages ready for online trading. Retrieved August 30, 2004 from http://www.internetnews.com/bus-news/print.php/6_588721

Asian technology newsletter. (2001, February 23). Focus: Online stock brokerage enablers in China. Business Development Asia, 6.

Brailsford, T. J., Frino, A., Hodgson, A. \& West, A. (1999). Stock market automation and the transmission of information between spot and futures markets. Journal of Multinational Financial Management, 9 (3-4) November, 247-264.

China e-Commerce Yearbook. (2003). Beijing. 
China Securities Regulatory Commission. (2004). Retrieved August 8, 2004 from http://www.chinaonline.com/refer/ministry_profiles/CSRC.asp

China's big bug problem. (2004). Retrieved October 13, 2004 from http://newpaper.asia1.com.sg/printfriendly/0,4139,74890,00.htm

Factbook. Shanghai Stock Exchange. (2004). Retrieved September 3, 2004 from http://www.sse.com.cn/about/factbook/factbook_us2002.pdf

Grunbichler, A., Longstaff, F.A. \& Schwartz, E. S. (1994). Electronic screen of trading and the transmission of information: An empirical examination. Journal of Financial Intermediation, 3, 166-187.

GSCS Benchmarks. (2002). Looking west with caution. The Review of Emerging Markets 2002. Retrieved September 1, 2004 from http://www.gscsbenchmarks.com/pdfs/emerging2002.pdf

Hamilton, J. (1978). Marketplace organization and marketability: NASDAQ, the stock exchange, and the national market system. Journal of Finance, 33, 478-503.

Internet World Stats. (2004). Usage and population statistics. Retrieved September 15, 2004 from http://www.internetworldstats.com/stats3.html

Jassawalla, M. (1989). The impact of telematics on financial intermediaries and market interdependencies. In M. Jassawalla \& T. Okuma (Eds.), Information technology and global interdependence. New York.

Levitt, A. (1989). The view from the American Stock Exchange. In H. C. Lucas, Jr. \& R. A. Schwartz, (Eds.), The challenge of information technology for the securities markets: Liquidity, volatility, and global trading (117-122). The Saloman Brothers Centre for the Study of Financial Institutions.

Malone, T., Yates, J. \& Benjamin, R. (1987). Electronic markets and electronic hierarchies: Effects of information technology on market structure and corporate strategies. Communications of the ACM, 30 (6), 484-497.

Nabi, M. G. (2004). Bangladesh Stock Markets: Their Necessity and Potential. Retrieved August 4, 2004 from http://www.csebd.com/cse/Publications/Portfoilio_Q1_2000/stockmarkets.htm

NETS progresses into interconnection trial phase. (1993, May 25). Beijing: Jinrongshibao.

Picot, A., Bortenlaenger, C. \& Roehrl, H. (1995). The automation of capital markets. Journal of ComputerMediated Communication. Retrieved August 4, 2004 from http://www.ascusc.org/jemc/voll/issue3/picot.html

Satellite communication for Shenzhen Stock Exchange. (1994, September 24). Beijing: Jinrongshibao.

Satellite information system operates in NETS progresses into interconnection trial phase. (1993, May 25). Beijing: Jinrongshibao.

Schroeder, P. (1991, May/June). Rebuilding China's securities markets. China Business Review, 18 (3), 2021.

Sender, H. (1994, February 24). China: Learning from others. Far Eastern Economic Review, 52.

Shanghai and Shenzhen successfully implemented new version of satellite software. (1993, November 1). Beijing: Jinrongshibao.

Shanghai Stock Exchange factbook. (2001). Retrieved September 3, 2004 from http://www.sse.com.cn/en_us/cs/about/factbook/factbook us2001.pdf

Soloman, K. (1996). Securities markets and China's international economic integration. Journal of International Affairs, Winter, 49 (2), 525-556.

Spam most destructive in China's Internet security. (2004). Retrieved September 21, 2004 from http://english.people.com.cn/200409/14/eng20040914_156990.html

Statistical report of the development of China Internet (1997.10). (2003). Retrieved April 14, 2003 from http://www.cnnic.net.cn/develst/9710/e-9710.shtml 
Statistical report of the development of China Internet (2004/7). (2004).Retrieved September 15, 2004 from http://www.cnnic.net.cn/download/2004/2004072002.pdf

Stock exchanges shorten suspended trading time. (2004). Retrieved September 3, 2004 from http://www.chinaonline.com/default 020327.asp

Wei, W. (1992). Steady development of Shanghai Stock Exchange. Beijing Review, 35 (8), 20-22.

Zhejiang disseminates stock market information via satellite. (1993, July 4). Beijing: Jinrongshibao.

Zhong, W. (2002, September 4). Online stock trades rises. Hong Kong iMail (China). Retrieved August 31, 2004 from http://0-search.epnet.com.library.vu.edu.au:80/direct.asp?an=2W81772820145\&db=buh

\section{Biography}

Dr Michelle W. L. Fong is a senior lecturer in the School of Applied Economics, Victoria University. Her research interest includes information technology systems and business systems. 